\title{
Indigenous knowledge and rangelands' biodiversity conservation in Tanzania: success and failure
}

\author{
Ismail Saidi Selemani ${ }^{1}$
}

Received: 13 May 2020 / Revised: 21 September 2020 / Accepted: 3 October 2020 /

Published online: 9 October 2020

(C) Springer Nature B.V. 2020

\begin{abstract}
Tanzania is one of the African countries endowed with diverse rangeland's biological resources hosting 6 out of 25 globally known biodiversity hotspots. Despite, government efforts on biodiversity conservation, the pressures on rangelands' biodiversity utilization are growing in line with increasing human population. With little recognition of contribution of local knowledge in biodiversity conservation, the current paper reviewed the potential of available indigenous knowledge in Tanzania and challenges limiting adoption of this vital knowledge on rangeland's biodiversity conservation. This review established that, the country has rich indigenous knowledge potential for rangeland management and biodiversity conservation. Traditional enclosures and pastoral mobility are among the important indigenous practices used for rehabilitation of degraded rangelands and conservation of fragile ecosystems. The coexistence of local communities with complex ecosystems offers them excellent experiences on rangelands' biodiversity conservation. However, increasingly loss of rangelands' biodiversity in the country is attributed to ignoring the contribution of local communities which are rich in indigenous knowledge and skills on rangelands management. Among of the challenges hindering the adoption and involvement of indigenous knowledge to conservation are; scientific bias toward pastoral communities, loss of local expertise, poor knowledge inheritance systems, poverty, conflicts and emergence of pandemic diseases. For effective and sustainable utilisation of indigenous knowledge, the following are recommended; fully engagement of local communities in conservation process, empowering local communities to reduce poverty and conflicts, mainstreaming the indigenous knowledge to conservation education, emphasising on livelihoods diversification to reduce reliance on biological resources and promoting studies to document existing indigenous knowledge.
\end{abstract}

Keywords Biodiversity · Conservation · Ecosystem · Indigenous knowledge $\cdot$ Rangeland management

Communicated by Peter Bridgewater.

This article belongs to the Topical Collection: Biodiversity appreciation and engagement.

Ismail Saidi Selemani

ismal.selemani@sua.ac.tz

Extended author information available on the last page of the article 


\section{Introduction}

Rangelands are critical areas for biodiversity conservation in terms of genetic materials (Kideghesho et al. 2013) and are sources of livelihoods to many communities living in arid and semi-arid regions; providing feed for both livestock and wildlife, medicinal plants and other diverse ecosystems services (Abule et al. 2007). Tanzania rangelands cover more than $74 \%$ of total land of 88.6 million hectares (Mwilawa et al. 2008) comprising about $74 \%$ of plants species found in East Africa (Goldman 2011; Kideghesho et al. 2013). Because of their ecological value and socio-economic importance, these rangelands are home to most spectacular wildlife population attracting substantial tourism revenues in the country (Homewood et al. 2012; Kidegesho 2001). On the other hands, most pastoral communities in Tanzania derive their livelihoods from rangeland resources. Currently, Tanzania is a second country in Africa after Ethiopia with largest livestock population harbouring about 30.5 million cattle, 18.8 million goats and 5.5 million sheep (URT 2017). Most of these livestock (99\%) are managed under traditional pastoralism/or agropastoralism in rangelands (Mwilawa et al. 2008) sharing forage and water resources with wildlife in competitive and facilitative manner (Nelson 2012).

Besides, heavy utilization pressure on rangeland resources resulting from cultural behaviour of most pastoralists stocking larger herds of livestock than the carrying capacity of land coupled to increasing wildlife population, pastoralists and wildlife managed to coexist and survive environmental stress for long time (Nelson 2012). The complex pastoral management system involving adaptation of harsh conditions in highly scarce heterogeneity forage and water resources is a results of pastoralists' indigenous knowledge and strategies on rangeland management and biodiversity conservation (Godana 2016; Saruni 2016). Historically, pastoral communities in Tanzania have relied on the rich indigenous knowledge to manage their environments and maintain resilience (Saruni 2016; Selemani et al. 2012). Using indigenous and Local Knowledge (ILK), pastoralists manage their lands through locally devised rules, by-laws, principles and code of conducts. Besides global initiatives which encouraging the interface of academia, pastoralism and policy (IUCN 2016), this vital local knowledge in East Africa is normally ignored in academic and scientific arena (Saruni 2016; Roba and Oba 2009). Nevertheless, little has been documented with regard to the role of indigenous knowledge on rangeland resources management and biodiversity conservation in Tanzania. In this context, the paper first outlines the status and contribution of rangeland resources to communities' livelihoods, review existing literature and summarize the usefulness of available indigenous knowledge from different pastoral communities in Tanzania and challenges underpinning adoption of indigenous knowledge in range management.

\section{Status of rangeland resources and biodiversity conservation in Tanzania}

Tanzania is one of the African countries endowed with diverse rangeland resources comprising about $74 \%$ of total land in the country (Kideghesho et al. 2013; Mwilawa et al. 2008). These rangelands are situated in a highly varied ecosystem and topographic features ranging from highland zones with an average annual rainfall of $2700 \mathrm{~mm}$ (Mwakisunga and Majule 2012) and dryland zones with low (less than $600 \mathrm{~mm}$ ) and unpredictable rainfall (Selemani et al. 2013). Approximately, about $80 \%$ of land in Tanzania is classified as semi-arid receiving relatively lower and unpredictable rainfall (Selemani 
2014). These characteristics rendered most of rangelands worldwide being unsuitable for rain-fed agriculture and hence considered as unproductive (Vetter 2005). However, in Tanzania rangelands are ideal for livestock grazing and tourism attraction due to their unique flora and fauna resources (Mwilawa et al. 2008). Vegetation types vary with climatic condition, soil characteristics and management regime mostly dominated with dense bush land and grassland with scattered wood vegetation (Selemani 2014). Miombo woodlands which cover $90 \%$ of forestland in Tanzania are integral parts of rangeland resources providing good and services to rural and urban communities (Lupala et al. 2015; Ruvuga et al. 2020). Rangelands in Tanzania are known as home to number of wildlife species recognized in the world (Kideghesho et al. 2013). It has extensive diversity of species with at least 14,500 known and confirmed species and is among 15 countries globally with the highest number of endemic as well as threatened species and also accounts for more than one-third of total plant species in Africa (VOP 2015). The country hosts about 6 out of 25 globally known biodiversity hotspots with a rich spectrum of fauna and flora. Wade et al. (2001) reported that, Tanzania is privileged with diverse wildlife, good scenery and unspoiled and attractive environment for tourists making the tourism the second leading foreigner exchange earner in the country after agriculture. About $20 \%$ of the African large mammals and nine rare and endangers species of birds are found in Tanzania (Miller et al. 1989).

Pressures on rangelands' biodiversity utilization are growing in line with increasing human population (Kidegesho et al. 2007). The rapid human population growth in Tanzania which results into increased rates of unsustainable consumption of resources and changes in land uses is the underlying cause for biodiversity loss (Kideghesho 2001; Selemani 2014). With current increasing anthropogenic activities such as expansion of crop production and settlements, most rangelands in Tanzania are increasing experiencing some form of exploitation pressures and hence become degraded (Selemani 2014). On the other hands, overexploitation of rangeland resources is associated with tremendous increase in both wildlife and livestock population resulting into changes in botanical composition (replacing perennial by annual species) and nutritional quality of forage by increasing unpalatable species against palatable one (Selemani and Sangeda 2019). Increasing bush encroachment and invasive species due to heavy grazing pressure resulting to suppression of herbaceous vegetation production is very common in most Tanzanian rangelands. Lyimo et al. (2019) reported some major impacts associated with bush encroachment and invasive species in different parts of country which include but not limited to loss of biodiversity, disappearance of certain species of fauna and flora which in turn resulted to social and economic distress to human livelihoods. Using economic value approach, Kirui (2016) concluded that, the annual cost for land degradation due to land use and land cover changes in Tanzania is approximately $\$ 2.3$ billion which is equivalent to $13.7 \%$ of the country GDP.

Different strategic efforts to restore degraded rangelands and conserve biological resources have been made with limited capacity. Tanzania government through different policy reform such as Tanzania Livestock Modernization initiatives of 2015 and Tanzania livestock Master Plan of 2017 to 2022 has prioritized rangeland rehabilitation and improvement in the country. The plan is to increase grazing land from 10 to $13 \%$ and promoting establishment of improved pasture/fodder production from $0 \%$ to at least $5 \%$ (URT 2017). Despite the promising plans, critical challenges remain, threatening the sustainability of the rangeland and natural resources. The UNDP (2016) paper highlighted some of the challenges limiting rangeland management and biodiversity conservation which include but not limited to unsustainable harvesting and use of natural resources, 
unchecked cultivation practices, bush encroachment and invasive species resulted from the impacts of climate change. All of these challenges can seriously undermine the country's efforts toward achievement of sustainable development goals if remains unaddressed.

The current global debate on the potential use of indigenous knowledge on rangeland management and biodiversity conservation has brought attention to researchers and land practitioners. Historically, pastoral communities relied on their indigenous knowledge and experiences to manage their rangeland resources. While, international recognition of indigenous knowledge on rangeland management is gaining momentum, the development and implementation of framework for integrating local communities and ecological methods in some parts of Africa have made limited progress (Roba and Oba 2009). According to Saruni (2016), indigenous knowledge is normally ignored in academic research and policy circles. Scientific bias of viewing local pastoralists as one of the agents of environmental degradation has always creates hostility between herders and ecologists (Benjaminsen et al. 2009). The equilibrium ecological theory that strongly linked the degradation of rangelands by the pastoralists' culture of overstocking appears to ignore the potential use of indigenous knowledge possessed by these pastoralists (Roba and Oba 2009; Vetter 2005). With these views, there is scanty information regarding the role and state of indigenous knowledge on rangeland management and biodiversity conservation in Tanzania and elsewhere. The proceeded sections reviewed different sources and summarized the role of indigenous knowledge on rangeland resources management and challenges hindering utilization of indigenous knowledge and practices.

\section{Role of indigenous and local knowledge in rangelands}

Sustainable rangeland management required weaving of Indigenous and Local Knowledge (ILK), traditional practices and strategies (Tengö et al. 2017). Solomon et al. (2007) maintained that, any attempt toward improvement of rangeland resources require through understanding of ILK and perceptions of local communities. According to Godana (2016) and Hill et al. (2020), the ILK are skills, practices and technologies that are integral part of production system in particular culture. In the context of range management, these are specific skills and practices used by specific society for rangeland and natural resources management. Saruni (2016) hold that, indigenous traditional land contained about $80 \%$ of global biodiversity of which local people are practicing their Indigenous and Local Knowledge for conserving natural resources and environmental management at large. In Tanzania context, there are more than 100 distinct customary institutions (ethnic groups and tribes, traditional religious groups, women's groups and social groups) each with specific inherited Indigenous and Local Knowledge potential for natural resources management (Lwoga et al. 2017). These local organizations are responsible for management and empowering of the indigenous people for better-informed decision with regard to use of ILK. This article cited few key indigenous pastoral communities as representative cases in Tanzania regarding the potential available indigenous skills and practices.

\section{Traditional enclosure and rangeland restoration}

Enclosure has emerged as a successful ecological rehabilitation tool for degraded rangelands in arid and semi-arid regions of Africa (Nyberg et al. 2019; Verdoodt et al. 2009; Wairore et al. 2015). Although, Nyberg et al. (2019) uphold that enclosures are not only panacea for dry land development, establishment of enclosures has become an important 
measure to combat land degradation in semi-arid rangelands (Verdoodt et al. 2009). Tradition reserved land (enclosure) has been used as indigenous practices for many years among pastoral and agro-pastoral communities in Tanzania to provide dry season feeds for livestock and promote environmental conservation (Mwilawa et al. 2008). These enclosures influence restoration of depleted rangelands by allowing quick vegetation recovery. Angassa et al. (2010) reported significant higher herbaceous biomass yield, grass basal cover, species richness and diversity in enclosed land than grazed land in Southern Ethiopia. Similarly, Selemani et al. (2013) established significantly higher biomass yield and vegetation cover in the enclosures of North Western Tanzania compared to open land. Given the shrinkage of grazing land in Tanzania, many pastoral communities in the country are shifting from pastoral mobility strategy to enclosure practices. These enclosures are well managed by respective ethnic groups or tribes using devised local rules and regulations (Table 1).

In Sukumaland, North-Western part of Tanzania ngitili has been proven as one of the successfully traditional management systems for rangeland management and forestry restoration (Kamwenda 2002). The system is farmer-lead Initiatives evolved from traditional grazing management used by pastoralists and agro-pastoralist as drought coping mechanisms. It involve reserving pasture as standing hay during rainy season and allowed for grazing during the peak of dry season when forage resources are scarce. Historically, ngitili evolved in 1980s' as pastoralists' initiatives in response to acute shortage of forages occurred as a result of increased human population pressure (Barrow and Shah 2011; Selemani et al. 2013). These ngitili have been practiced for many years as drought coping strategy among sukuma people before abandoned in 1970s' as results of ujamaa villagization programme (Pye-Smith 2010). Ujamaa villagization scheme forced pastoralists to settle in ujamaa villages and abandon their traditional pastoral practices including ngitili management. Disrupting pastoral systems by increasing sedentarisation drives a population boom which strains the fragile ecosystem. In 1980s' ngitili practice was revived in response to acute shortage of forage resources (Barrow and Mlenge 2003). According to Kamwenda (2002) two key powerful institutions are used in management of ngitili namely; traditional village guards (sungusungu) and village assemblies (dagashida). In 1986, the tradition ngitili management was reinforced by the government initiative named "Hifadhi Ardhi Shinyanga" (HASHI), the project funded by Norwegian government (Pye-Smith 2010) which enabled restoration of approximately 400,000 ha of ngitili by 2002 (Barrow and Shah 2011). In addition to forage improvement and forestry restoration, ngitili in Sukuma land plays significant role in soil conservation and reduction of soil erosion.

In Maasailand, tradition pasture reserves are well known as Alalili and are practiced in response to the declined pastoral mobility due to expansion of protected areas and crop

Table 1 Different Ethnic groups practicing enclosure in Tanzania

\begin{tabular}{|c|c|c|c|}
\hline $\begin{array}{l}\text { Local name of } \\
\text { enclosure }\end{array}$ & $\begin{array}{l}\text { Ethnic } \\
\text { group }\end{array}$ & Regions in Tanzania & References \\
\hline Ngitili & Sukuma & $\begin{array}{l}\text { Shinyanga, Simiyu, Tabora, Mwanza, } \\
\text { Geita }\end{array}$ & Pye-Smith (2010) \\
\hline Olopololi/Alalili & Maasai & Arusha, Manyara, Tanga, Morogoro & Goldman (2011) \\
\hline Milanga & Gogo & Dodoma, Singida & Njau et al. (2013) \\
\hline Radanenda & Barbaig & Manyara, Arusha & $\begin{array}{l}\text { Kilongozi et al. } \\
\text { (2004) }\end{array}$ \\
\hline
\end{tabular}


production. Historically, Maasai were mobile pastoralists, searching for quality pasture and water and the Alalili were only used for sick animals or calves (Goldman 2011). However, increasing sedentarisation forced Maasai pastoralists to use Alalili as important pasture reservation strategy for their livestock. It is adaption mechanism to the effect of climate change and variability (Goldman and Riosmena 2013). Mapinduzi et al. (2004) pointed out that, Alalili is one of the powerful Indigenous and Local Knowledge used by Maasai for dry season feed reserves and biodiversity conservation. Alalili is normally managed by elders through individual boma, or groups of bomas or entire village (Goldman 2011).

The Gogo people in the central part of Tanzania have similar practices of conserving forage resources for dry season feeds. Like Alalili in Maasai, Milanga is a common indigenous practice in central region of the country. According to Njau et al. (2013), Gogo people are among the leading pastoralists with high livestock population in the country and thus are facing with challenge of poor availability and quality of forage. Therefore, tradition reserved pastures (Milanga) used by Gogo tribes is a cheap source of dry season feeds for cattle, goats and sheep (Mwilawa et al. 2008). Similar ILK was noted from the Barbaig tribe, where the council of elders manages pasture reserves known as Radanenda for their livestock as drought coping mechanism (Kilongozi et al. 2004).

\section{Indigenous and local knowledge on biodiversity conservation}

Based on the Convention on Biological Diversity (CBD) the term "Biodiversity" refers to variability among living organisms and ecological complexes of which they are integral part of it (CBD 2001). The rapid declining in the world biological diversity can be explained by several factors including, habitat destruction, land use changes, overexploitation of biological resources, climate change and invasive species (Rawat and Agrawal 2015). Degradation of rangelands due to increasing anthropogenic activities results to loss of habitats for several species. Biodiversity loss has several consequences to people since it lowers the capacity of ecosystems to provide good and services to human being. With recognition of the value of biodiversity, the Convention on Biological Diversity emphasizes on achieving three objectives; conservation of biological diversity, sustainable utilization of biological resources and equitable sharing of benefits accrued from utilization of genetic resources (Bennett 2004).

Biodiversity conservation in Tanzania faces many challenges include but not limited to increased crop production, overgrazing, overexploitation of biological resources due to increased human population and climate change. The rapid human demographic growth has resulted into overexploitation of biological resources beyond the capacity of available resources (Kideghesho et al. 2013). Agriculture is among the most leading human activities contributing significantly to habitat loss. Newmark (2008) cautioned that, the rapid disappearance of habitats in Tanzania if not checked will impact species survival and ecological functioning. Recognizing the important of biodiversity conservation, the government of Tanzania concentrated her conservation efforts to protected areas (National Parks, Game Reserves, Game Controlled Areas, Wildlife Management Areas Conservation Areas and Forest Reserves) which cover only $32.5 \%$ of the total land in the country (NAFORMA 2015). More than 65\% of the total land is unprotected and hence vulnerable to habitats loss due to increasing unchecked human activities (Fig. 1). Nevertheless, most of wildlife species are mobile and hence most of time found outside protected areas exposing themselves into the risk of disappearance. Nelson (2012) reported that many species of mammals such as elephants, wildebeest and zebra undertake annual migrations 
Fig. 1 Land use cover in Tanzania. Source NAFORMA (2015)

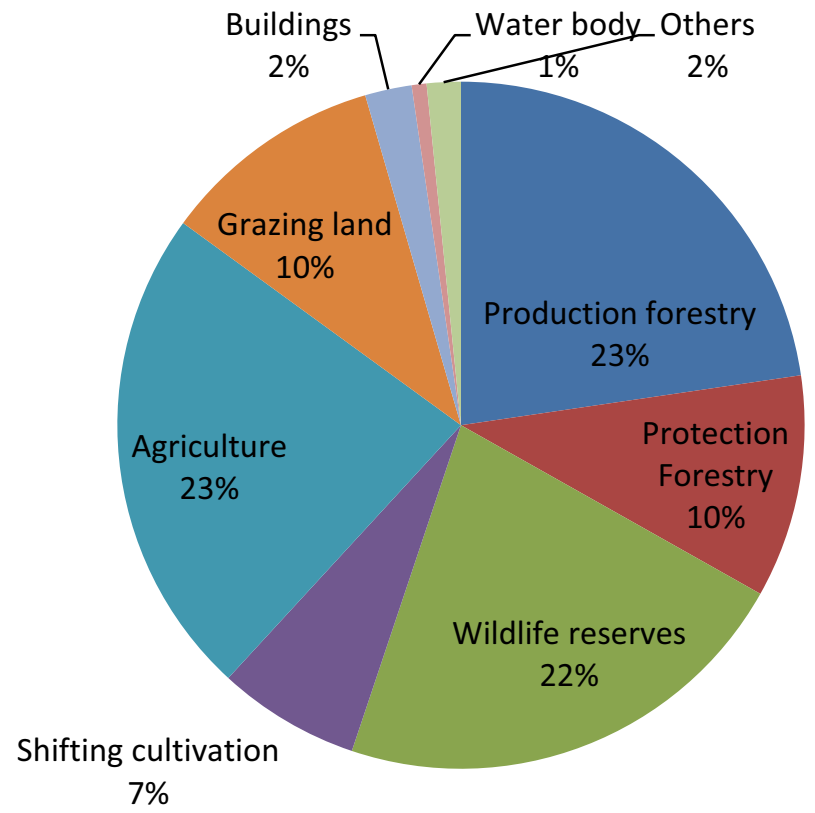

outside protected areas based on seasonal availability of forage and water resources. However, the synergies between wildlife and local communities surrounding protected areas and historical coexistence of wildlife and pastoralists is underexplored (Homewood et al. 2012). This necessitates the need to explore the contributions of local communities (occupying larger habitats) on biodiversity conservation using their indigenous knowledge.

Generally, Indigenous and Local Knowledge in Eastern Africa has been previously ignored and neglected in the management of natural resources and biodiversity conservation (Bruno et al. 2018). Recently, it has been realized that, conservation of biodiversity is hardly possible without involving local communities endowed with rich conservation skills and strategies (Carvalho and Frazao-Moreira 2011). According to Bruno et al. (2018), there is strong relationship between ILK and biodiversity conservation. Tanzania like other African countries has transformed from the fence-and-fine approach to Community Based Conservation (CBC) which embraces the contribution of local communities on biodiversity conservation (Noe and Kangalawe 2015). The fundamental concept behind the $\mathrm{CBC}$ is to empower local communities using their respective institutions to conserve biological resources in their private or communal lands (Noe and Kangalawe 2015). With this understanding, both the pastoralists and agro-pastoralists who live adjacent to protected areas have a very long traditional culture and experience of protecting the environment whereby they coexist with nature with little disturbance. For example, in Ngorongoro Conservation Area, Maasai pastoralists have historically managed to coexist with wildlife. This synergy has made the Indigenous Maasai people maintain their cultural heritage and the rest of the biodiversity without harming them. On the contrary, the attempt made in 1974, on removing Maasai pastoralists from Ngorongoro crater resulted into declined of herbivore diversity (Nelson 2012). It was therefore concluded that, presence of Maasai and their livestock has no detrimental effects to any single wildlife species both in Ngorongoro and Serengeti ecosystem (Nelson 2012). 


\section{Proper grazing management}

Indigenous and Local Knowledge has cultural significance and play vital roles on management of natural habitats through sustainable use of available resources. Most local pastoralists in Tanzania have ability to identify and assess plant species based on their nutritive values, biomass yield, medicinal plants and plants with impacts on animal performance. For example, Maasai elders play central role in assessment of range suitability for grazing animals (Table 2). These traditional ecological Indigenous and practice enable them to make proper decision on how to conserve their ecosystem. Nevertheless, pastoral mobility and deferred grazing systems are two main strategies adopted by pastoralists to conserve their fragile ecosystems. Adriansen (2005), described pastoral mobility as a necessary adaptive strategies (particularly in dryland) ensure rangeland health by reducing grazing pressure through migrations to other areas with high quality forage and water resources. Historically most of key pastoralists in Tanzania (Maasai, Sukuma, Gogo and Barbaig) used to practice mobility to various parts of country before draft shift to deferred grazing systems as described above.

\section{Conservation of key valuable plants in the rangelands}

Local communities have long experience on identification of key valuable plant species such as medicinal plants or plants with high economic values in the society. Moshi et al. (2010), reported that, local people from the North-Western Tanzania have rich culture of traditional herbal plants due to their inter-ethnic interactions with different people such as Rukiga and Banyakole from Uganda and Tutsi and Hutu from Rwanda. Although utilization of medicinal plants is condemned to cause local species extinction (da Silva et al. 2019), most elders have Indigenous and Local Knowledge of identifying key plant species required priority for conservation. For example, plants such as Ageratum conyzoides, Biden pilosa, Boerhavia diffusa, Caparis tomentesa, Combretum collinum and Latana camara have been given conservation priorities by Haya people due to their potential medicinal value (Moshi et al. 2010). In addition to medicinal plants, some tress species are strictly conserved due to their cultural values in particular society (Table 3). It has been reported that, some tree species such as Comiphora species and Adansonia digitata are given conservation attention because they are linked with ancestors the beliefs which symbolized the relationship between sky and Earth (Hines and Eckman 1993).

Table 2 Range condition assessment using Maasai local knowledge

\begin{tabular}{ll}
\hline $\begin{array}{l}\text { Range } \\
\text { condition }\end{array}$ & Ecological attributes \\
\hline $\begin{array}{l}\text { Good range } \\
\begin{array}{c}\text { Evough pasture, adequate water, good soil, short distance to grazing, less disease incidence } \\
\text { and few or no predators. }\end{array} \\
\begin{array}{l}\text { Adequate forage, long distance to water, few diseases, incidences, few predators } \\
\text { Bad range }\end{array}\end{array}$ \\
\hline
\end{tabular}

Source Kilongozi et al. (2004) 
Table 3 Some trees with significant cultural value in Tanzania

\begin{tabular}{llll}
\hline S/N & Tree species & Cultural value & Ethnic groups \\
\hline 1 & Comiphora ugogoensis & Ritual purposes, dyes & Gogo, Sukuma \\
2 & Ficus sycomonus & Associated with good luck & Gogo, Zigua, Rangi \\
3 & Trichilia emetica & Shades, Ritual, Medicine & Chaga, Bondei, Zigua \\
4 & Grewia bicolar & Used for shades & Gogo, Luguru, Zaramo \\
5 & Euphorbia candelabrium & Expel evil spirits & Gogo, Chaga \\
6 & Ficus thonningii & Provide shades & Zigua, Fipa, Iraqw \\
7 & Bridelia micrantha & Extraction of dyes & Hehe, Nyamwezi \\
8 & Combretum adenogonium & Medicine, shades & Hehe, Yao, Nyamwezi \\
\hline
\end{tabular}

Source Hines and Eckman (1993)

\section{Challenges hindering adoption of indigenous and local knowledge in Tanzania}

Besides, the critical roles play by Indigenous and Local Knowledge and skills on rangeland management and biodiversity conservation in Tanzania, degradation of rangelands and loss of biodiversity is a growing trend (Kideghesho et al. 2013). It has been noted that, rangeland biodiversity loss is attributed mainly to human activities resulting into habitat destruction, overexploitation of species, introduction of exotic species and the effects of climate change and variability. The use of ILK and practices on rangeland biodiversity conservation in Tanzania has been constrained by number of factors. This section presented briefly the challenges limiting integration of Indigenous and Local Knowledge with ecological methods used for rangeland management.

\section{Erosion of indigenous and local knowledge and scientific bias}

Indigenous societies are generally aware of the importance of biodiversity conservation through experience and practical skills inherited mainly from elders. However, the Indigenous and Local Knowledge on natural resources management is wide world threatens by growing globalisation. According to Sujarwo et al. (2014) indigenous communities are rapidly changing their cultures under the influence of western models. Most young pastoralists in Tanzania are transforming their tradition culture and life styles to western culture. For example, Maasai Morans are currently migrating to towns and cities and become engaged in different activities such as guards and saloon activities. Although, such cultural changes are considered as livelihoods diversification (McCabe et al. 2014), they bear the consequences on erosion of ILK important for natural resource management. Disconnection between the young warriors and elders with rich indigenous knowledge, is adversely affecting inheritance of indigenous knowledge. However, in the face of their continuous and alarming erosion rate, ILK is increasing gaining attention in the international arena. For example, among of the objectives of the Intergovernmental Platform on Biodiversity and Ecosystem Services (IPBES) is to ensure that the best available ILK is incorporated in the national or international frameworks on biodiversity conservation (Tengö et al. 2017; UNESCO 2019). 
Despite the good will of weaving the Indigenous and Local Knowledge to the conservation initiatives but building synergies between ILK and science remains a challenge. Saruni (2016), uphold that, ILK has been ignored in academic and scientific arena. According to Roba and Oba (2009), scientific bias is attributed to academic training of natural scientists whose understandings are influenced exclusively by scientific methods and theories. Besides scientific bias, local communities and individuals partly contribute to their own marginalisation and exclusion from mainstreaming the ILK to rangeland management and biodiversity conservation. The ways of learning, storing and transmitting knowledge have partly contributed to the erosion of Indigenous and Local Knowledge as people often "ring fenced" their expertise or died without transferring it to next generations (Maunganidze 2016).

\section{Land use conflicts and poverty}

Overexploitation of natural resources in Tanzania is partly attributed to poverty among pastoral communities. Tanzania is classified among the least developed countries in the world (Kideghesho et al. 2013). Homewood et al. (2012) described pastoral communities living in Arid and Semi-arid regions as among the poorest groups affected by extreme climatic events. These marginalised groups derived their livelihoods from the harsh environments by extracting natural resources from rangelands. However, increasing human population pressure overwhelmed the ability of local communities to conserve their biological resources using their indigenous knowledge. Increasing environmental scarcity is a driving force for conflicts between different land users (Benjaminsen et al. 2009). The land use conflicts may results into destruction of natural resources and rangelands' biodiversity through burning or improper cultivation.

\section{Emerging pandemic diseases}

Emergence of pandemic diseases such as HIV/AIDS and COVID 19 are undoubtedly affecting all development sectors including natural resources management. Apart from increasing disappearance of labour forces as result of these pandemic diseases, biodiversity conservation is indirectly endangered. The rapid decline in the national economy and household income due to pandemic diseases resulted into reliance on natural resources from rangeland for human survival (Kideghesho et al. 2013). With such economic crisis, local people engage in harvesting of rangeland resources such as timbers, charcoal making, and collection of firewood, building materials and fodders for livestock. Besides, the possession of the ILK on biodiversity conservation, the socio-economic demands forces communities to over-utilize these resources beyond the production capacity. In addition to harvesting rangelands' goods, the unsustainable harvesting of medicinal plants for treating pandemic diseases has resulted to biodiversity losses. For example, the current outbreak of COVID 19, created huge demand of medicinal plants in Tanzania, that could significantly affect biodiversity conservation. Although, to date, there is no cure for COVID 19, numerous traditional herbs and trees have been used by different ethnic groups for supressing corona virus in Tanzania (Table 4). 
Table 4 Some medicinal plants used locally for treating COVID 19 in Tanzania. Source Adopted from Zahabu and Temu (2020)

\begin{tabular}{lll}
\hline S/N & Botanical name & Local name (Ethnic group) \\
\hline 1 & Ocimum suave & Mzumbashi (Sambaa) \\
2 & Asparagus asparagoides & Shungamzinga (Sambaa) \\
3 & Piectranthus barbatus & Ighombo (Chaga) \\
4 & Vangueria tomentosa & Mvule (Swahili) \\
5 & Zehnenia scabra & Fuiza \\
6 & Senecio syringifolia & Ulenge (Sambaa) \\
7 & Timeria grandfolia & - \\
8 & Conyza newii & Ikowe (Chaga) \\
9 & Clausena anisota & - \\
10 & Drymaria cordata & Ugwiashingi (Sambaa) \\
11 & Psidium guajava & Mpera (Swahili) \\
12 & Rhus natolensis & Mhunguu (Sambaa) \\
13 & Latana camara & Mvuti (Sambaa) \\
14 & Eucalyptus species & Mkaratusi (Swahili) \\
15 & Venonia lasiopus & Mhasha (Sambaa) \\
\hline
\end{tabular}

\section{Conclusion}

This review established that, local communities in Tanzania possess useful Indigenous and Local Knowledge potential for rangeland management and biodiversity conservation. The coexistence of local communities with complex ecosystems and diverse living species enabled them to gain experiences on rangelands' biodiversity conservation. For example, it has been noted that, the traditional enclosures and pastoral mobility are two important key indigenous practices used by pastoral communities for rehabilitation of degraded rangelands and conservation of fragile ecosystems. Using indigenous knowledge, pastoral communities have ability to identify and classify rangeland conditions into conservation priorities. This includes conservation of endangered species and species with high economic and ecological values in the community. However, increasingly loss of rangelands' biodiversity in the country is to the large extent attributed to ignoring the contribution of local communities which are rich in ILK and skills on rangelands management. Little incorporation of ILK to the ecological conservation methods and national managerial frameworks is linked to the negative perceptions pervade among scholars of viewing local pastoral communities as driver of environmental degradation.

With recognition of contribution of indigenous knowledge, Tanzania like other African countries has adopted the Community Based Conservation (CBC) approach that empowers local communities toward conservation of biodiversity using their Indigenous and Local Knowledge and practices. Despite the government initiatives to engage local communities, the utilization of ILK in the country has limited progress. The numbers of challenges have been reported to hinder the adoption and integration of Indigenous and Local Knowledge to management of rangelands and conservation of biological resources. Poor involvement of Indigenous and Local Knowledge to ecological and conservation methods is one the main challenge associated with scientific bias resulted from training of natural scientists based on western scientific methods and theories. Besides, erosion of ILK and skills is partly contributed to the behavioural and cultural changes as results of globalisation. The ways of learning, storing and transmitting knowledge have contributed to the erosion of 
ILK as people often "ring fenced" their expertise or died without transferring it to next generations. In addition, land scarcity and emerging pandemic diseases exposed local communities to extreme poverty and conflicts which in turn resulted into overexploitation of biological resources.

For effective and sustainable utilisation of Indigenous and Local Knowledge in rangeland's biodiversity conservation a number of issues are recommended as conservation measures. Firstly, local communities should be fully engaged in conservation process from decision making to implementation of targeted plans. This will empower local communities and hence reduce bias and conflicts among rangeland stakeholders. Secondly, studies aiming for documenting existing Indigenous and Local Knowledge and practices should be promoted. Thirdly, the ILK should be mainstreamed to conservation education from lower levels (in secondary schools) to higher levels (university). Lastly, local communities should be empowered to diversify their livelihoods which in turn will reduce reliance on biological resources from rangelands.

\section{Compliance with ethical standards}

Conflict of interest The author declared that, there is no conflict of interest with regard to this article.

\section{References}

Abule E, Snyman HA, Smit GN (2007) Rangeland evaluation in the Middle Awash Valley of Ethiopia: II. Woody vegetation. J Arid Environ 70:272-292

Adriansen HK (2005) Pastoral mobility. Nomadic People 9:207-214

Angassa G, Oba G, Treydte AC, Waladji RB (2010) Role of traditional enclosure on diversity of herbaceous vegetation in semi-arid rangelands,\&nbsp;Southern Ethiopia. Livest Rural Res Dev 22(9):163

Barrow E, Mlenge W (2003) Trees as key to pastoralist risk management in semi-arid landscapes in Shinyanga, Tanzania and Turkana, Kenya. In: Paper presented at the international conference on rural livelihoods, forests and biodiversity, 19-23 May, Bonn, Germany

Barrow E, Shah A (2011) TEEBcase: traditional forest restoration in Tanzania. TEEweb.org

Benjaminsen A, Maganga FP, Abdallah JM (2009) The kilosa killings: political ecology of farmer-herder conflicts in Tanzania. Dev Change 40(3):423-445

Bennett B (2004) Integrating biodiversity conservation and sustainable use: lessons learned from ecological networks. IUCN, Gland, Switzerland, and Cambridge, UK, p vi +55

Bruno TMR, Cédric CD, Phanuella DS, d'Estaing NA, Valery NN, Nfornkah BN, Funwi FP, Roger KBLP, Christian ZJ, Jean-Paul AN, Frank WP1, Roger NL, Zapfack LZ (2018) Indigenous and local knowledgeas a tool for wildlife conservation in the Dja biosphere reserve, cameroon. Int J Soc Sci Hum Res 6(4):148-156

Carvalho AM, Frazao-Moreira A (2011) Importance of indigenous knowledge in plant resources management and conservation in two protected areas from Tras-Os-Montes. Portugal J Ethno Ethnomed 7:36

CBD (2001) Secretariat of the Convention on Biological Diversity (2001) Assessment and management of alien species that threaten ecosystems, habitats and species. Abstracts of keynote addresses and posters presented at the sixth meeting of the Subsidiary Body on Scientific, Technical and Technological Advice, held in Montreal, Canada, from 12 to 16 March 2001. CBD Technical Paper no. 1

da Silva NF, Hanazaki N, Albuquerque UP, Campos JLA, Feitosa IS, Araújo E (2019) Indigenous and local knowledgeand conservation priorities of medicinal plants near a protected area in Brazil. Hindawi Evid-Based Complement Altern Med. https://doi.org/10.1155/2019/8275084

Godana DG (2016) The role of indigenous knowledge in rangeland management in Yebello Woreda Southern Oromia, Ethiopia. Arts Soc Sci J 7(2):1-8

Goldman MJ (2011) Strangers in their own land: maasai and wildlife conservation in Northern Tanzania. Conserv Soc 9(1):65-79

Goldman MJ, Riosmena F (2013) Adaptive capacity in Tanzanian Maasailand: changing strategies to cope with drought in fragmented landscapes. Global Environ Change 23(3):588-597

Hill R, Adem Ç, Alangui WV, Molnár Z, Aumeeruddy-Thomas Y, Bridgewater P, Tengö M, Thaman R, Yao CYA, Berkes F, Carino J, da Cunha MC, Diaw MC, Díaz S, Figueroa VE, Fisher J, Hardison P, 
Ichikawa K, Kariuki P, Karki M, Lyver POB, Malmer P, Masardule O, Yeboah AAO, Pacheco D, Pataridze T, Perez E, Roué M, Roba H, Rubis J, Saito O, Xue D (2020) Working with indigenous, local and scientific knowledge in assessments of nature and nature's linkages with people. Curr Opin Environ Sustain 43:8-20

Hines DA, Eckman K (1993) Indigenous multipurpose tree of Tanzania. Use and economic benefits for people. FAO, Rome, p 221 p

Homewood C, Trench PC, Brockington D (2012) Pastoralist livelihoods and wildlife revenues in East Africa. A case of coexistence? Pastoralism 2(19):1-23

IUCN (2016) Integrating traditional knowledge into red list assessments. In: Workshop paper \#9744 presented at the IUCN WCC 2016 on 2 September, Honolulu, Hawai'i

Kamwenda GJ (2002) Ngitili silvipastoral system in the United Republic of Tanzania. Unasylva 53:46-50

Kideghesho J, Rija AA, Mwamende KA, Selemani IS (2013) Emerging issues and challenges in conservation of biodiversity in the rangelands of Tanzania. Nat Conserv 6:1-29

Kidegesho JR, Roskaft E, Kaltenborn BP (2007) Factors influencing conservation attitudes of local people in Western Serengeti, Tanzania. Biodivers Conserv 16:2213-2230

Kideghesho JR (2001) Mitigating the loss of wildlife habitats in Tanzania: current and future strategies. Tanzania J For Nature Conserv 74:149-161

Kilongozi N, Kengera Z, Leshongo S (2004) The utilization of indigenous and local knowledgein range management and forage plants for improving livestock productivity and food security in the Maasai and Barbaig Communities of KIBAHA. A case Study report. http://www.fao.org/3/a0182e/A0182E00. htm\#TOC

Kirui OK (2016) Economics of land degradation and improvement in Tanzania and Malawi. In: Nkonya E, Mirzabaev A, von Braun J (eds) Economics of land degradation and improvement-a global assessment for sustainable development. Springer, Cham, pp 609-648

Lupala ZJ, Lusambo LP, Ngaga YM, Makatta AA (2015) The land use cover change in miombo woodlands under community based forest management and its implication to climate change mitigation: a case of Southern Highland Tanzania. Int J For Res 2015:11

Lwoga ED, Ngulube P, Stilwell C (2017) Indigenous knowledge management practices in indigenous organizations in South Africa and Tanzania. In: Ngulube P (ed) Handbook of research on social, cultural, and educational considerations of indigenous knowledge in developing countries. IGI Global, pp 181-201. https://doi.org/10.4018/978-1-5225-0838-0.ch010

Lyimo JG, Kangalawe RYM, Liwenga ET (2019) Status, impact and management of invasive alien species in Tanzania. Tanzania J For Nat Conserv 79(2)

Mapinduzi AL, Oba G, Weladji RB, Colman JE (2004) Use of indigenous ecological knowledge of the Maasai pastoralists for assessing rangeland biodiversity in Tanzania. Afr J Ecol 41(4):329-336

Maunganidze L (2016) A moral compass that slipped: indigenous knowledge systems and rural development in Zimbabwe. Cogent Soc Sci 2:1-12

McCabe JT, Smith NM, Lesile PW, Telligman AL (2014) Livelihood diversification through migration among a pastoral people: contrasting case studies of Maasai in Northern Tanzania. Hum Organ 73(4):389-400

Miller RI, Stuart SN, Hwell KM (1989) A methodology for analysing rare species distribution patterns utilizing GIS technology. Rare Birds Tanzania Landsc Ecol 2(3):173-189

Moshi J, Otieno DF, Mbabazi PK, Weisheit A (2010) Ethnomedicine of the Kagera Region, northwestern Tanzania. Part 2: the medicinal plants used in Katoro Ward, Bukoba District Mainen. J Ethnobiol Ethnomed 6:19

Mwakisunga B, Majule AE (2012) The influence of altitude and management on carbon stock quantities in rungwe forest, southern highland of Tanzania. Open J Ecol 2(4):214-221

Mwilawa AJ, Komwihangilo DM, Kusekwa ML (2008) Conservation of forage resources for increasing livestock in traditional forage reserves in Tanzania. Afr J Ecol 46:85-89

NAFORMA (2015) National forestry resources monitoring and assessment of Tanzania Mainland: mmain results. TFS survey report. http://www.fao.org/forestry/43612-09cf2f02c20b55c1c00569e679197dcde.pdf

Nelson F (2012) Natural conservationists? Evaluating the impact of pastoralists land use practices on Tanzania's wildlife economy. Pastoralism 15(2):1-19

Newmark WD (2008) Isolation of African protected areas. Front Ecol Environ 6(6):321-328

Njau FBC, Lwelamira J, Hyandye C (2013) Ruminant livestock production and quality of pastures in the communal grazing land of semi-arid central Tanzania. Livest Res Rural Dev. 25:146

Noe C, Kangalawe RYM (2015) Wildlife protection, community participation in conservation and (dis) empowerment in Southern Tanzania. Conserv Soc 13(3):244-253

Nyberg G, Mureithi SM, Muricho DN, Ostwald M (2019) Enclosures as a land management tool for food security in African drylands. J Land Use Sci 14(1):110-121 
Pye-Smith C (2010) Rural revival in Tanzania. How agro-forestry is helping farmers to restore woodlands in Tanzania. ICRAF trees for change, 7th edn. World Agroforestry Centre, Nairobi

Rawat US, Agarwal NK (2015) Biodiversity: concepts, threats and conservation. Environ Conserv J 16(3):19-21

Roba HG, Oba G (2009) Efficacy of integrating herder knowledge and ecological methods for monitoring rangeland degradation in Northern Kenya. Hum Ecol 37(5):589-612

Ruvuga PR, Wredle E, Mwakaje A, Selemani IS, Sangeda AZ, Nyberd G, Kronqvist C (2020) Indigenous rangeland and livestock management among pastoralists and agro-pastoralists in Miombo woodland, Eastern Tanzania. Rangeland Ecol Manag 73:313-320

Saruni K (2016) Indegeneous knowledge systems and rangeland governance in Northern Tanzania. Tanzania J Pop Stud Dev 23:1-31

Selemani IS (2014) Communal rangelands management and challenges underpinning pastoral mobility in Tanzania: a review. Livest Res Rural Dev 26(5):2014

Selemani IS, Sangeda AZ (2019) Spatial and temporal vegetation dynamics: opportunities and constraints behind wildlife migration in Eastern Africa Savanna Ecosystem. In: Kideghesho J, Rija A (eds) Wildlife management-failures, successes and prospects. IntechOpen Publishers, London, pp 10-21

Selemani IS, Eik LO, Holand $\varnothing$, Ådnøy T, Mtengeti EJ, Mushi DE (2012) The role of Indigenous and Local Knowledgeand perceptions of pastoral communities on traditional grazing management in northwestern Tanzania. Afr J Agric Res 7:5537-5547

Selemani IS, Eik LO, Holand Ø, Ådnøy T, Mtengeti E, Mushi D (2013) The effects of a deferred grazing system on rangeland vegetation in a north-western, semi-arid region of Tanzania. Afr J Range For Sci 30(3):141-148

Solomon TB, Snyman HA, Smit GN (2007) Cattle-rangeland management practices and perceptions of pastoralists towards rangeland degradation in the Borona zone of Southern Ethiopia. J Environ Manag 82:481-494

Sujarwo W, Arinasa IBK, Salomone F, Fattorin S (2014) Cultural erosion of balinese indigenous and local knowledgeof food and nutraceutical plants. Econ Bot 68(4):426-437. https://doi.org/10.1007/s12231014-9288-1

Tengö M, Hill R, Malmer P, Raymond CM, Spierenburg M, Danielsen F, Elmqvist T, Folke C (2017) Weaving knowledge systems in IPBES, CBD and beyond-lessons learned for sustainability. Curr Opin Environ Sustain 26-27:17-25

UNDP (2016) Environmental sustainability, climate change and resilience strategy Paper 1

UNESCO (2019) Linking indigenous and scientific knowledge to counter biodiversity erosion. https://en. unesco.org/news/linking-indigenous-and-scientific-knowledge-counter-biodiversity-erosion

URT (2017) Tanzania livestock master plan of 2017/2018-2021/2022. Government report, p 126

Verdoodt A, Mureith SM, Ye L, Van Ranst E (2009) Chronosequence analysis of two enclosure management strategies in degraded rangeland of semi-arid Kenya. Agric Ecosyst Environ 129(1-3):332-339

Vetter S (2005) Rangelands at equilibrium and non-equilibrium: recent development in debate. J Arid Environ 62:321-341

VOP (2015) Biodiversity in Tanzania. Biodiversity information exchange platform. http://tz.chm-cbd.net/ biodiversity

Wade DJ, Mwasanga BC, Eagles PFJ (2001) A history and market of tourism in Tanzania. Tourism Manag 22:93-101

Wairore JN, Mureithi SM, Wasonga OV, Nyberg G (2015) Characterization of enclosure managementregimes and factors influencing their choiceamong agropastoralists in North-Western Kenya. Pastoralism 14(5):1-10

Zahabu E, Temu RPC (2020) Types of trees recommended for treatment of Corona Virus. Leaflet, p 4

Publisher's Note Springer Nature remains neutral with regard to jurisdictional claims in published maps and institutional affiliations.

\section{Affiliations}

\section{Ismail Saidi Selemani ${ }^{1}$}

1 Department of Animal, Aquaculture and Range Sciences, Sokoine University of Agriculture (SUA), P. O. Box 3004, Morogoro, Tanzania 